НАУКОВИЙ ВІСНИК

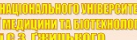
and

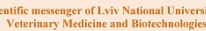
7.

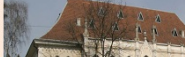
11 MIMMV: Tin: 18 in

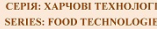
Том 23 № 96 2021
Науковий вісник Дьвівського національного університету ветеринарної медицини та біотехнодогій імені С.3. Гжицького. Серія: Харчові технології

\section{Scientific Messenger of Lviv National University} of Veterinary Medicine and Biotechnologies.

Series: Food Technologies https://nvlvet.com.ua/index.php/food

UDC 664:663.674

\title{
Research of quality indicators of parfe ice cream with vegetable fillers
}

\author{
N. B. Slyvka ${ }^{1}$, O. Ya. Bilyk ${ }^{1}$, G. V. Dronyk ${ }^{2}$, V. O. Nagovska ${ }^{1}$ \\ ${ }^{1}$ Stepan Gzhytskyi National University of Veterinary Medicine and Biotechnologies Lviv, Lviv, Ukraine \\ ${ }^{2}$ Bukovinian State Agricultural Research Station of the Institute of Agriculture of Carpathian Region of NAAS, \\ Chernivtsi, Ukraine
}

Article info

Received 20.05.2021

Received in revised form

21.06.2021

Accepted 22.06.2021

Stepan Gzhytskyi National University of Veterinary Medicine and Biotechnologies Lviv,

Pekarska Str., 50, Lviv, 79010, Ukraine.

Tel.: + 38-067-275-37-25

E-mail: slyvkanat@ukr.net

Bukovinian State Agricultural Research Station NAAS

Bogdan Kryzhanivskyi Str., 21, Chernivtsi, 58026, Ukraine. Tel.: +38-037-252-92-20.
Slyvka, N. B., Bilyk, O. Ya., Dronyk, G. V., \& Nagovska, V. O. (2021). Research of quality indicators of parfe ice cream with vegetable fillers. Scientific Messenger of Lviv National University of Veterinary Medicine and Biotechnologies. Series: Food Technologies, 23(96), 76-81. doi: $10.32718 /$ nvlvet-f9613

The ice cream market is one of the developed segments of the food industry of Ukraine. Ice cream is a frozen product that is consumed all over the world. The work aimed to investigate the quality of parfait ice cream with vegetable fillings. The selection and justification of the components of the system, namely quail eggs, celery root, spinach leaves, was based on literature data and regulatory documentation, as well as laboratory data. Celery and spinach puree was chosen as one of the recipe components of ice cream, and the peculiarities of its preparation were studied. Parfait ice cream recipes with different ratios of vegetable fillers and pumpkin flour have been developed. The physiological and organoleptic parameters of ice cream with additional pumpkin flour, celery, and spinach puree were studied. According to the obtained results, the optimal content of pumpkin flour in ice cream is equal to 2-4\%, and vegetable puree - 25-35\%. It has been proved that pumpkin flour significantly affects the structural characteristics of ice cream mixes. They were melting resistance increases from 100 to 145 minutes. When increasing the flour content to $4 \%$. The dry matter content in ice cream varies depending on the amount of vegetable puree and pumpkin flour. However, the mass fraction of fat and dry nonfat milk residue does not change because the experimental samples were developed based on the composition of the control sample. Studies show that the new frozen dessert retains microbiological stability for six months. The combination of vegetable and dairy raw materials with pumpkin flour and quail eggs in the production of parfait ice cream provides the necessary whipping. It allows obtaining a product with specified rheological and physicochemical parameters.

Key words: ice cream, pumpkin flour, celery and spinach puree, fillers.

\section{Дослідження якісних показників морозива парфе 3 овочевими наповнювачами}

\author{
Н. Б. Сливка ${ }^{1}$, О. Я. Білик ${ }^{1}$, Г. В. Дроник ${ }^{2}$ В. О. Наговська ${ }^{1}$
}

${ }^{1}$ Львівський національний університет ветеринарної медицини та біотехнологій імені С. 3. Гэсицького, м. Львів, Україна

${ }^{2}$ Буковинська державна сільськогосподарська дослідна станція Інституту сільського господарства Карпатського регіону Національної академії аграрних наук України, м. Чернівці, Україна

Ринок морозива є одним з розвинених сегментів харчової промисловості Украйни. Морозиво - це заморожений продукт, який вживають у всьому світі. Метою роботи було дослідити якісні показники морозива парфе з овочевими наповнювачами. Вибір $i$ обтрунтування компонентів системи, а саме яєць перепелиних, кореня селери, листя шпинату базувався на літературних даних $i$ нормативній документаиії, а також даних лабораторних досліджень. Одним із рецептурних компонентів морозива було обрано пюре із селери і шпинату та досліджено особливості його приготування. Розроблено рецептури морозива парфе із різним співвідношенням овочевих наповнювачів та гарбузового борошна. Досліджено фізико-хімічні й органолептичні показники морозива з різним вмістом гарбузового борошна і пюре селери та шпинату. За сукупністю одержаних результатів обрано оптимальний 
вміст гарбузового борошна в морозиві, ияо дорівнює 2-4\%, а овочевого пюре - 25-35\%. Доведено, ияо гарбузове борошно суттєво впливає на структурні характеристики сумішей для морозива. Опір до танення збільшується із 100 до 145 хв при збільшенні вмісту борошна до 4 \%. Вміст сухих речовин у морозиві змінюється залежно від кількості овочевого пюре та гарбузового борошна. Проте масова частка жиру та сухого знежиреного молочного залишку не змінюється, оскільки дослідні зразки розроблялися, виходячи зі складу контрольного зразка. Проведені дослідження свідчать, щуо новий заморожений десерт зберігає мікробіологічну стабільність протягом 6 місячів. Комбінування овочевої та молочної сировини із використанням гарбузового борошна і перепелиних яєць при виробництві морозива парфе забезпечує необхідну збитість і дає змогу отримати продукт із заданими реологічними $i$ фізико-хімічними показниками.

Ключові слова: морозиво, гарбузове борошно, пюре селери та шпинату, наповнювачі.

\section{Вступ}

Адекватне харчування є обов'язковим для життєзабезпечення. Людина потребує достатньої їжі для росту, розвитку та активного і здорового життя. Проте структура споживання їжі у світі значно змінилася, оскільки доведено, що здорове харчування може відновити баланс між системами організму, зменшуючи ризик захворювань (Polishchuk \& Hudz, 2006). Молочні продукти $\epsilon$ важливою складовою здорового харчування. Улюбленими ласощами не тільки дітей, а й дорослих є морозиво (Didukh, 2006).

Морозиво - це комплекс колоїдної системи, яка у замороженому стані складається 3 кристалів льоду, повітряних клітин, краплин жиру тощо (Polishchuk et al., 2008; Polishhuk, 2012; Bilyk et al., 2021). Різновидом морозива $\epsilon$ парфе, яке виготовляють 3 вершків масовою часткою жиру 35 \%, яєць і цукру. Воно характеризується високою калорійністю і $є$ високожирним продуктом (Al-Farsi \& Lee, 2008; Rybak \& Polishchuk, 2009). Рослинні компоненти у ньому відсутні, тому для сучасної людини такий продукт є непривабливим, адже перевагу надають продуктам оздоровчого призначення із збалансованим складом. Тому включення до рецептур парфе фруктів, ягід, овочів дозволить підвищити вміст вітамінів і мінеральних речовин та створити продукт з абсолютно новими функціональними властивостями та оригінальним смаком (Ahmed et al., 1995; Kuliev et al., 2008; Kulkarni \& Joshi, 2013).

Золотисто-зелені овочі визнані такими, що зміцнюють здоров'я, завдяки вмісту поживних речовин. Серед них - шпинат і селера, які багаті на біологічно активні речовини.

Селера $є$ поширеним інгредієнтом на кухнях у всьому світі. Стебла селери багаті на целюлозу складний вуглевод, що міститься в клітинній стінці рослин, їстівний, але не засвоюваний людиною. Селера має низький глікемічний індекс - 35. Вона має мінімальну кількість жирних кислот та білка, багата на мікроелементи. У селері велика кількість калію, натрію та фтору, фолієвої кислоти, холіну, вітаміну А та K (Turchyn et al., 2018).

Шпинат є хорошим джерелом білка, клітковини та мінералів, тим самим його використання формує функціональність нового продукту з високими харчовими та біологічними цінностями. Шпинат є багатим джерелом основних мікроелементів, таких як залізо, марганець, цинк та магній, а також містить невелику кількість вітаміну Е, А, C, K, B $1, \mathrm{~B}_{6}$ та $\mathrm{B}_{2}$.

Біологічно активні речовини шпинату і селери здатні відбирати активні форми кисню та запобігати окисному впливу макромолекул, модулювати експресію та активність генів, що беруть участь у метаболізмі, проліферації, запаленні та антиоксидантному захисті. Також вони ведуть до зниження апетиту, індукуючи секрецію гормонів ситості (Polishchuk \& Hudz, 2006).

При виробництві заморожених десертів використовується значна кількість як вітчизняних, так і імпортних інгредієнтів. Обов'язковими рецептурними компонентами при виробництві таких продуктів $\epsilon$ стабілізаційні системи, емульгатори, компаунди та ін. Багато стабілізаторів мають білкову природу i ïx отримують із рослинної сировини (Park et al., 1997). При аналізі літературних даних встановлено, що різні види борошна мають високий вміст білків, володіють вологозв'язуючими та жирозв'язуючими властивостями і можуть використовуватися як харчові добавки для стабілізації структури харчових середовищ. До таких продуктів відносять і борошно з насіння гарбуза, яке містить близько 80 \% вуглеводів, 6 \% білка, $5 \%$ мінеральних речовин, 42,2 мг/\% каротину. Гарбузове борошно використовується також через оригінальний смак, солодкість і насичений жовто-оранжевий колір (Park et al., 1997; Pongjanta et al., 2006). Слід зазначити, що гарбузове борошно - безглютеновий продукт, тому рекомендоване людям, які страждають непереносимістю глютену і соєвого білка (Muse \& Hartel, 2004; Pongjanta et al., 2005; Siems et al., 2006).

Тому, зважаючи на цінні властивості шпинату, селери та гарбузового борошна, доцільним буде включити ї до рецептур заморожених десертів 3 метою розширення їх асортименту, зниження калорійності морозива парфе та створення оздоровчого продукту.

\section{Матеріал і методи досліджень}

Відбір проб для досліджень здійснювали відповідно до ГОСТ 8764-73, ГОСТ 26185-84.

Вибір і обгрунтування компонентів системи, а саме яєць перепелиних, кореня селери, листя шпинату базувався на літературних даних і нормативній документації, а також даних лабораторних досліджень.

Одним із рецептурних компонентів морозива було обрано пюре із селери і шпинату та досліджено особливості його приготування.

Для деструкції протопектину й збільшення кількості розчинного пектину свіжий корінь селери проварюють у підкисленому середовищі ( $\mathrm{pH} 2,7-3,3)$ при температурі 80-85 ${ }^{\circ} \mathrm{C}$ з витримкою 20-25 хв рН 2,7 приводить до зростання кислотності у готовому продукті, а вище 3,3 деструкція протопектину, що знаходиться в стінках оболонок рослинних клітин, незначна.

Листя шпинату бланшують у підкисленому середовищі (рH 2,7-3,3) при температурі 80-85 ${ }^{\circ} \mathrm{C}$ з ви- 
тримкою 5-7 хв.

Після термообробки селеру і шпинат подрібнюють за допомогою блендеру (1500 об/хв) протягом 2-3 хвилин.

Співвідношення селери і шпинату $-1: 1$.

Дослідженнями встановлено вміст сухих речовин у пюре селери - $12,3 \%$, а у пюре шпинату $-8,9 \%$.

Овочеве пюре вносили у кількості 20, 25, 30, 35, 40 \% від маси суміші морозива парфе.

Здатність молочних білків утворювати піну є однією $з$ причин їх використання при виробництві заморожених десертів. Оскільки при виробництві десерту парфе основним компонентом $є$ молочні вершки, то із молочної сировини запропоновано у рецептуру включити вершки 3 масовою часткою жиру 40 \% та сухе знежирене молоко як джерело білків.

Цукор надає не лише солодкуватий смак готовому продукту, але й формує структуру і консистенцію морозива парфе.

Перепелине яйце важить лише 10 грамів. Але цей продукт $є$ потужним джерелом вітамінів та мінералів, які сприяють зміцненню імунної системи та запобігають вірусним захворюванням. Перепелині яйця лідирують серед тваринних продуктів за вмістом калію та заліза - 620 мг\% і 400 мг\% відповідно. Тобто, одне яйце забезпечує добову норму споживання калію на $31 \%$ та заліза на $18 \%$. Також вони багаті на кальцій, фосфор, мідь і кобальт. Білок перепелиного яйця містить 3 незамінних амінокислоти: лізин, метіонін, триптофан. Серед вітамінів найбільше $є$ вітаміну $\mathrm{B}_{2}$, а також A, E, PP, B .

Контрольний зразок було виготовлено за традиційною рецептурою, до якої входять вершки, яйця курячі, цукор і молоко.

Кількість гарбузового борошна варіювали від 1 до $5 \%$.

Органолептичні дослідження допомагають виявити вади смаку та запаху сировини та напівфабрикатів, а також готового продукту з метою своєчасного усунення причин їх появи. Зовнішній вигляд і колір продукту визначають візуально; консистенцію, структуру і смак морозива - органолептично. Органолептична оцінка, яку проводять шляхом дегустації, - це оцінка реакції органів відчуття на властивості харчових продуктів, що може бути визначена за допомогою якісних і кількісних методів. На сьогоднішній день широко розповсюджений метод бальної оцінки згідно 3 умовно прийнятими багатобальними системами.

Для органолептичної оцінки якості морозива застосовують 100-бальну і 10-бальну системи. Проте 100-бальна система відрізняється складним багаторівневим оцінюванням якості морозива, тому ми вибрали оцінювання органолептичних властивостей морозива за 10-бальною шкалою. У такому випадку бали розподіляють так:

- зовнішній вигляд - 1 бал

- структура і консистенція - 3 бали

- запах, смак і аромат - 6 балів

Кількість морозива для оцінки якості одного зразка становить 15 г.

Масову частку сухої речовини в морозиві визначають арбітражним методом шляхом висушування проби при температурі 102-105 ${ }^{\circ} \mathrm{C}$ та експресметодом при висушуванні проби при температурі $180{ }^{\circ} \mathrm{C}$. Для визначення масової частки жиру у морозиві з вмістом жиру згідно рецептурного розрахунку не більше 7,5 \% у жиромір для молока відважують 5 г морозива 3 точністю до 0,01 г та обережно, під нахилом жироміра, додають до нього близько $16 \mathrm{~cm}^{3}$ сірчаної кислоти (густина 1500-1550 кг/м³), щоб рівень рідини був на 4-5 мм нижчим за звуження жироміра біля отвору. Потім вносять $1 \mathrm{~cm}^{3}$ ізоамілового спирту. Жиромір закривають пробкою та струшують, потім перевертають його декілька разів так, щоб рідина у ньому повністю перемішалася.

Жиромір з рідиною ставлять у водяну баню $з$ температурою $70{ }^{\circ} \mathrm{C}$ на 15 хв для повного розчинення білків та періодично струшують. Потім жиромір ставлять у центрифугу, де проби центрифугують чотири рази по 5 хв. при частоті обертання 1200 об./хв. Після кожного центрифугування жиромір витримують протягом 5 хв. на водяній бані при температурі $65-70{ }^{\circ} \mathrm{C}$. По закінченні центрифугування та витримуванні жироміра за його шкалою знімають показники. Для визначення масової частки жиру у відсотках показники жироміра множать на коефіцієнт 2,2. Розбіжності між паралельними показниками жироміра при паралельних визначеннях допускаються не більші за одну поділку шкали жироміра. При меншій частоті обертання центрифуги виконують п’яте, контрольне центрифугування. При визначенні масової частки жиру у молочному морозиві з негомогенізованої суміші застосовують одноразове центрифугування. Частота обертання центрифуги повинна бути не меншою за 1000 об./хв.

При визначенні масової частки жиру у морозиві 3 вмістом жиру згідно рецептурного розрахунку більше 7,5 \% у жиромір для вершків відважують 5 г морозива 3 точністю до 0,01 г та додають близько $16 \mathrm{~cm}^{3}$ сірча-

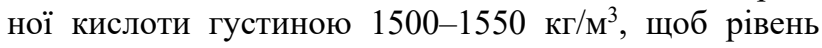
рідини був на 6-10 мм нижчим основи звуження жироміра біля отвору. Розбіжності між паралельними визначеннями допускаються до 0,5 \%. Жироміри центрифугують якнайменше 4 рази. При визначенні вмісту жиру у морозиві з негомогенізованої суміші застосовують однократне центрифугування 3 частотою обертання центрифуги 1000 об./хв.

У випадку визначення титрованої кислотності незабарвленого морозива порядок досліджень такий. У конічну колбу місткістю 100 або $250 \mathrm{~cm}^{3}$ відважують 5 г продукту, додають $30 \mathrm{~cm}^{3}$ дистильованої води та три краплини 1 \%-ного розчину фенолфталеїну. Суміш ретельно перемішують та титрують 0,1 моль/дм ${ }^{3}$ розчином $\mathrm{NaOH}$ або КОН до появи слаборожевого забарвлення, що не зникає протягом 1 хв. Кислотність у градусах Тернера розраховують шляхом множення кількості витраченого на нейтралізацію лугу на коефіцієнт 20.

Розміри жирових кульок визначають мікроскопічним методом зі збільшенням не менше, ніж у 400-600 разів $(10 \times 40$ або $15 \times 40)$. Внаслідок високого вмісту у сумішах сухих речовин проба повинна бути підготовлена перед випробовуванням шляхом 50-100-кратного розведення дистильованою водою. Краплину розведеної суміші поміщають на предметне скло, накривають 
покривним склом, фільтрувальним папером видаляють надлишок вологи 3 країв покривного скла та за допомогою окуляр-мікрометра із заздалегідь визначеною ціною поділки встановлюють розміри жирових кульок. Для цього жирові кульки розбивають на групи, розраховують їх середні діаметри за групами та середньозважений діаметр жирових кульок загалом у суміші.

Визначення розмірів повітряних бульбашок. Пробу морозива наносять на тарировану сітку камери Горяєва, зверху накривають покривним склом та відразу ж мікроскопіюють. Кристалики льоду при цьому розплавляються, але піна зберігається, бо за цих умов оболонки повітряних бульбашок не зневоднюються. Зразки мікроскопіюють при збільшенні у 400 разів. При розрахунку середнього діаметра повітряних бульбашок об'єм газу приводять до нормальних умов.

Для визначення збитості морозива на виході 3 фризеру використовують склянку ємністю від 50 до $200 \mathrm{~cm}^{3}$. Одну і ту ж склянку по черзі зважують пустою, з сумішшю і з морозивом. Склянка повинна бути сухою і чистою. Склянку заповнюють сумішшю або морозивом врівень 3 краями. Продукт, що виступає за межі склянки, обережно знімають ложечкою або ножем. При заповненні склянки морозивом не допускаються пустоти.

Визначення опору морозива до танення. Зразок м'якого або загартованого морозива температурою відповідно мінус 6 або мінус $18{ }^{\circ} \mathrm{C}$ відбирають спеціальним пробником у вигляді пустотілого циліндра діаметром 35 мм та висотою 50 мм та кладуть у паперовий 3 полімерним покриттям стаканчик 3 отворами по краю дна для вільного витікання рідкої суміші.

Опір танення виражають через тривалість накопичення $10 \mathrm{~cm}^{3}$ суміші (у хвилинах), що утворюється внаслідок розплавлення морозива у термостаті при температурі $25^{\circ} \mathrm{C}$. Цей показник залежить від збитості морозива, дисперсності повітря в продукті та вмісту у ньому вологи.

Густину сумішей морозива встановлюють ареометричним методом. Для цього застосовують два типи лактоденсиметрів - 3 термометром та без нього. Ціна поділки шкали у лактоденсиметрів першого типу 0,001, другого типу $-0,0005$.

Вимірювання проводять при температурі суміші $20{ }^{\circ} \mathrm{C}$. Дослідний зразок добре перемішують, обережно наливають по стінках у скляний циліндр місткістю $250 \mathrm{~cm}^{3}$. Чистий та сухий ареометр обережно занурюють у суміш до поділки шкали 1, 100 та залишають вільно плавати до встановлення постійного значення по шкалі. Для унеможливлення похибок вимірювання не допускається, щоб ареометр торкався стінок циліндра. Значення густини відраховують по верхньому краю меніска рідини.

\section{Результати та їх обговорення}

У табл. 1 наведено характеристику продукту із різною кількістю гарбузового борошна та овочевого пюре.

\section{Таблиця 1}

Органолептичні показники морозива парфе

\begin{tabular}{|c|c|c|c|}
\hline \multirow{2}{*}{ Показник } & \multicolumn{3}{|c|}{ Кількість внесення борошна/овочевого пюре, \% } \\
\hline & $1 / 20$ & $2-4 / 25-35$ & $5 / 40$ \\
\hline $\begin{array}{l}\text { Зовнішній ви- } \\
\text { гляд і консисте- } \\
\text { нція }\end{array}$ & $\begin{array}{c}\text { Парфе з грубою структу- } \\
\text { рою та тягучою консистен- } \\
\text { цією }\end{array}$ & $\begin{array}{c}\text { Парфе однорідної консистенції із дріб- } \\
\text { нодисперсною повітряною фазою та } \\
\text { високим опором до танення і збитістю }\end{array}$ & $\begin{array}{l}\text { Парфе } 3 \text { низькими збитіс- } \\
\text { тю та опором до танення }\end{array}$ \\
\hline Запах & $\begin{array}{c}\text { Чистий, характерний для } \\
\text { вершків, із ароматом селери }\end{array}$ & $\begin{array}{c}\text { Чистий, характерний для вершків, iз } \\
\text { вираженим запахом селери }\end{array}$ & $\begin{array}{c}\text { Чистий, із різким запахом } \\
\text { селери }\end{array}$ \\
\hline Смак & $\begin{array}{c}\text { Солодкуватий, з характер- } \\
\text { ним присмаком шпинату і } \\
\text { селери }\end{array}$ & $\begin{array}{c}\text { Солодкуватий, } 3 \text { смаком шпинату i } \\
\text { селери }\end{array}$ & $\begin{array}{c}\text { Солодкуватий, } 3 \text { смаком } \\
\text { шпинату і селери }\end{array}$ \\
\hline Колір & Однорідний, світло-зелений & $\begin{array}{l}\text { Однорідний, } \\
\text { салатовий }\end{array}$ & Однорідний, зелений \\
\hline
\end{tabular}

Встановлено, що внесення гарбузового борошна у кількості 2-4 \% від загальної маси та включення 25$35 \%$ овочевого пюре забезпечує формування належних органолептичних показників морозива.

1 \% гарбузового борошна не забезпечує високої збитості та опору до танення готового продукту.

Понад 4 \% гарбузового борошна значно підвищує в'язкість, погіршує диспергування повітря, знижує збитість. Оптимальна кількість внесення овочевого пюре становить 25-35 \% від маси суміші. Це підтверджується наведеними органолептичними показниками.

На основі експериментальних та розрахункових даних розроблено рецептури морозива парфе із різним співвідношенням компонентів.
Результати наведено у табл. 2.

Отже, на основі експериментальних та розрахункових даних розроблено рецептури морозива на молочній основі із різним співвідношенням компонентів.

Для отримання потрібної текстури нових продуктів та отримання піни важливою технологічною умовою є відповідна в'язкість харчового середовища, яка утворює пружній каркас i забезпечує стабільність дисперсійного середовища. В'язкість впливає на забезпечення збитості морозива та його опір таненню. Вона формує консистенцію морозива парфе. В'язкість суміші впливає на густину суміші, від якої залежить консистенція продукту. На густину суміші впливає вміст сухих речовин і жиру. 
Таблиця 2

Рецептури морозива парфе

\begin{tabular}{llccc}
\hline & \multicolumn{1}{c}{ Складові компоненти } & \multicolumn{2}{c}{ Вага, кг } \\
\cline { 3 - 5 } & Вершки (м.ч.ж. 40,0 \%, м.ч. СЗМ3 4,8 \%) & 313,5 & 313,5 & 313,5 \\
\hline 1 & Сухе знежирене молоко (м.ч. СЗМ3 96,0 \%) & 205 & 165 & 125 \\
2 & Гарбузове борошно (м.ч.ж. 1,6\%, м.ч. С3М3 90,0 \%) & 40,0 & 30,0 & 20,0 \\
3 & Овочеве пюре (м.ч. СР 10,0\%) & 250,0 & 300,0 & 350,0 \\
4 & Цукор (м.ч. СР 99,0 \%) & 146,5 & 146,5 & 146,5 \\
5 & Яйця перепелині & 45,0 & 45,0 & 45,0 \\
6 & Всього & 1000,0 & 1000,0 & 1000,0 \\
\hline
\end{tabular}

Також важливими показниками якості морозива є насичення його дрібними бульбашками повітря, тобто збитість. Цей показник теж залежить від в'язкості суміші. Чим вона більша, тим менші розміри повітряних бульбашок. Неправильна збитість (мала або висока) викликає вади морозива - від появи великих кристалів льоду чи крупинчастості при малій збитості, до крихкої, сніжної консистенції - при високій. Високий вміст сухих речовин та застосування стабілізаторів дозволяє збільшити збитість заморожених десертів. При високих кількостях цукру і жиру, а також рослинних наповнювачів збитість зменшується. Згідно нормативних вимог збитість має бути не менше $35 \%$.

Для отримання доброї консистенції морозива слід контролювати дисперсність повітряної фази. Якщо середній розмір повітряних бульбашок більше 60 мкм, то може утворюватися грубокристалічної структури морозива парфе. Розміри повітряних бульбашок обернено пропорційно залежать від в’язкості суміші.

Тому постає завдання - провести комплекс досліджень щодо визначення фізико-хімічних показників нового замороженого десерту.

Результати проведених досліджень показують, що вміст сухих речовин у морозиві змінюється залежно від кількості овочевого пюре та гарбузового борошна. Проте масова частка жиру та сухого знежиреного молочного залишку не змінюється, оскільки дослідні зразки розроблялися, виходячи зі складу контрольного зразка.

Зміна хімічного складу сумішей вплинула на в'язкість сумішей, збитість морозива. Про це свідчать дані табл. 3.

Таблиця 3

Фізико-хімічні показники морозива парфе

\begin{tabular}{|c|c|c|c|c|}
\hline Показник & Контроль & Дослід 1 & Дослід 2 & Дослід 3 \\
\hline 1 & 2 & 3 & 4 & 5 \\
\hline Кислотність, ${ }^{0} \mathrm{~T}$ & 16 & 26 & 28 & 32 \\
\hline Збитість, \% & 110 & 75,1 & 82,4 & 98,6 \\
\hline Коефіцієнт динамічної в’язкості суміші, мПа*с & 134,3 & 210,7 & 167,3 & 141,4 \\
\hline Густина, Г/см ${ }^{3}$ & 1,105 & 1,145 & 1,120 & 1,110 \\
\hline Опір до танення, хв & 100 & 145 & 120 & 105 \\
\hline Середній діаметр жирових кульок, мкм & 2,0 & 2,0 & 1,95 & 2,1 \\
\hline Середній діаметр повітряних бульбашок, мкм & 44 & 49 & 47 & 45 \\
\hline
\end{tabular}

Незначне збільшення густини у дослідних зразках обумовлене підвищенням вмісту сухих речовин борошна і зменшенням кількості молочних компонентів.

Зниження збитості у дослідних зразках морозива 3 різним вмістом гарбузового борошна обумовлене ускладненням диспергування повітря за надмірної в'язкості систем (141,4-210,7 мПа•с).

В результаті досліджень встановлено, що насичення повітрям у зразках з вмістом $2 \%$ борошна розподіляється подібно до контролю. Середній діаметр повітряних бульбашок у зразках із 3 і 4 \% гарбузового борошна становить 47 і 49 мкм, відповідно, а для контролю - 44 мкм. Тому використання гарбузового борошна попереджує виникнення борошнистої і піщанистої консистенції під час зберігання, транспортування та збуту морозива.

Також внесення рослинних добавок не впливає на розміри жирових кульок, які залежить від механічного оброблення сумішей морозива, тобто параметрів збивання.
Спостерігається підвищення опору до танення при збільшенні вмісту гарбузового борошна. Так, опір до танення збільшується при внесенні $2 \%$ - на 10,5\%, при внесенні $3 \%$ - $20 \%$, при внесенні 4\% - на $45 \%$. Це обумовлюється стабілізуючими та структуроутворюючими властивостями цього борошна.

Отже, комбінування овочевої та молочної сировини із використанням гарбузового борошна і перепелиних яєць при виробництві морозива парфе забезпечує необхідну збитість і дає змогу отримати продукт iз заданими реологічними і фізико-хімічними показниками.

Для визначення терміну та умов зберігання морозива парфе досліджено їх мікробіологічні показники при зберіганні протягом 6 місяців, які вказують на безпечність готових продуктів для споживачів.

Результати досліджень наведено у табл. 4.

Проведені дослідження свідчать, що новий заморожений десерт зберігає мікробіологічну стабільність протягом 6 місяців. 


\section{Таблищя 4}

Мікробіологічні показники морозива парфе

\begin{tabular}{|c|c|c|c|c|c|}
\hline & $\begin{array}{c}\text { МАФАнМ, } \\
\text { КУО/Г }\end{array}$ & $\begin{array}{c}\text { БГКП } \\
\text { (коліформи) }\end{array}$ & $\begin{array}{c}\text { Патогенні, } \\
\text { в т. ч. сальмонели }\end{array}$ & $\begin{array}{c}\text { Дріжджі, } \\
\text { КУО/г }\end{array}$ & $\begin{array}{l}\text { Цвілі, } \\
\text { КУО/г }\end{array}$ \\
\hline Контроль & $1,2 \times 10^{2}$ & не виявлено & не виявлено & не виявлено & не виявлено \\
\hline Дослід 1 & $1,2 \times 10^{2}$ & не виявлено & не виявлено & не виявлено & не виявлено \\
\hline Дослід 2 & $1,4 \times 10^{2}$ & не виявлено & не виявлено & не виявлено & не виявлено \\
\hline Дослід 3 & $1,5 \times 10^{2}$ & не виявлено & не виявлено & не виявлено & не виявлено \\
\hline $\begin{array}{l}\text { Нормативні } \\
\text { значення }\end{array}$ & $\begin{array}{c}\text { не більше } \\
5 \times 10^{3}\end{array}$ & $\begin{array}{c}\text { не допускаються в } \\
1,0 \text { г }\end{array}$ & $\begin{array}{c}\text { не допускаються в } \\
25,0 \text { г }\end{array}$ & не більше 50 & не більше 50 \\
\hline
\end{tabular}

\section{Висновки}

Розроблено рецептури морозива парфе із різним співвідношенням овочевих наповнювачів та гарбузового борошна.

Досліджено фізико-хімічні й органолептичні показники морозива з різним вмістом гарбузового борошна і пюре селери та шпинату. За сукупністю одержаних результатів обрано оптимальний вміст гарбузового борошна в морозиві, що дорівнює 2-4\%, а овочевого пюре - 25-35\%.

Доведено, що гарбузове борошно суттєво впливає на структурні характеристики сумішей для морозива. Опір до танення збільшується із 100 до 145 хв при збільшенні вмісту борошна до 4 \%.

\section{References}

Ahmed, I. A., Ahmed, A. W. K., \& Robinson, R. K. (1995). Chemical composition of date varieties as influenced by the stage of ripening. Food chemistry, 54(3), 305-309. doi: 10.1016/0308-8146(95)00051-J.

Al-Farsi, M. A., \& Lee, C. Y. (2008). Nutritional and functional properties of dates: a review. Crit Rev Food Sci Nutr., 48(10), 877-887. doi: 10.1080/10408390701724264.

Bilyk, O., Slyvka, N., Nagovska, V., \& Mykhaylytska, O. (2021). Development of ice cream recipe with dates processing products. Scientific Messenger of LNU of Veterinary Medicine and Biotechnologies. Series: Food Technologies, 23(95), 51-56. doi: 10.32718/nvlvetf9509.

Didukh, N. A. (2006). Morozyvo diabetychnoho pryznachennia "Karotynka". Molochnoe delo, 6, 12 (in Ukrainian).

Kuliev, N. Sh., Salomov, B. H., Ashurova, M. Z., \& Ganieva, N. (2008). Morozhenoe s fruktovo-ovoshhnymi stabilizatorami. Pishhevaja promyshlennost', 3, 38-39 (in Russian).

Kulkarni, A., \& Joshi, D. (2013). Nutritional, sensory and textural qualities of bhajjiya supplemented with pumpkin (Cucurbita maxima) powder. International Food Research Journal, 20(5), 3237-3241. URL: http://www.ifrj.upm.edu.my/20\%20(06)\%202013/37 \%20IFRJ\%2020\%20(06)\%202013\%20Kulkarni\%201 37.pdf.

Muse, M. R., \& Hartel, R. W. (2004). Ice cream structural elements that affect melting rate and hardness. J Dairy
Sci, $\quad 87(1), \quad 1-10 . \quad$ doi: $\quad 10.3168 /$ jds.S00220302(04)73135-5.

Park, Y., Cha, H., Park, M., Kang, Y., \& Seo, H. (1997). Chemical components in different parts of pumpkin. Journal of Korean Society of Food Science Nutrition, 26, 639-646.

Polishchuk, H. Ye., \& Hudz, I. S. (2006). Tekhnolohiia morozyva. K.: Firma (in Ukrainian).

Polishchuk, H. Ye., Rybak, O. M., \& Yaniuk, T. I. (2008). Doslidzhennia vplyvu zernovykh produktiv na stabilizatsiiu struktury morozyva. Molochna promyslovist, 5, 70-72 (in Ukrainian).

Polishhuk, G. E. (2012). Morozhenoe: sovremennye tehnologii i perspektivy razvitija. Mir produktov, 2(81), 32-36 (in Russian).

Pongjanta, J., Naulbunrang, A., Kawngdang, S., Manon, T., \& Thepjaikat, T. (2006). Utilization of pumpkin powder in bakery products. Songklanakarin Journal of Science and Technology, 28, 71-79. URL: https:/www.semanticscholar.org/paper/Utilization-ofpumpkin-powder-in-bakery-products-PongjantaNaulbunrang/24c3c9f09318b9bc898a817e7684 e6ffab198788.

Rybak, O. M., \& Polishchuk, H. Ie. (2009). Stabilizatsiia struktury morozyva boroshnom zernovykh kultur. Materialy vseukrainskoi naukovoi koferentsii Ternopilskoho derzhavnoho tekhnichnoho universytetu im. I. Poliuia, 13-14 travnia 2009r.: tezy dop. Ternopil: TDTU, 292 (in Ukrainian).

Rybak, O. M., \& Polishchuk, H. Ye. (2009). Vplyv vivsianoho boroshna na formuvannia yakisnykh pokaznykiv morozyva. Obladnannia ta tekhnolohii kharchovykh vyrobnytstv. Donetsk: DonDUET, 22, 388-396 (in Ukrainian).

Siems, S., Wiswedel, I., Salerno, C., Crifo, C., Augustin, L., Langhans, C., \& Sommerberg, O. (2005). $\beta$-Carotene breakdown products may impair mitochondrial functions - Potential side effects of high dose $\beta$-carotene supplementation. Journal Nutritional Biochemistry, 16(7), 385397. doi: 10.1016/j.jnutbio.2005.01.009.

Turchyn, I., Zalensky, M., \& Voychishin, A. (2018). Development of technology of cereal past with combined composition. Scientific Messenger of LNU of Veterinary Medicine and Biotechnologies. Series: Food Technologies, 20(85), 24-28. doi: 10.15421/nvlvet8505. 